\title{
Prevalence and risk factors for Toxoplasma gondii infection in certified and non-certified pig breeding farms in the Toledo microregion, PR, Brazil
}

Prevalência e fatores de risco para a infecção pelo Toxoplasma gondii em granjas de reprodutores suídeos certificados ou não da microregiâo de Toledo, PR, Brasil

Franciele Rossandra Piassa ${ }^{1}$ Jacqueline Baptista de Araújo ${ }^{1}$; Ronaldo César da Rosa ${ }^{2}$; Rodrigo José Mattei²; Rodrigo Costa da Silva ${ }^{3}$; Helio Langoni ${ }^{3}$; Aristeu Vieira da Silva ${ }^{4 *}$

${ }^{1}$ Universidade Paranaense - UNIPAR, bolsistas PIT/UNIPAR

${ }^{2}$ Universidade Paranaense - UNIPAR, bolsistas PIBIC/UNIPAR

${ }^{3}$ Departamento de Higiene Veterinária e Saúde Pública, Universidade Estadual Paulista - UNESP

${ }^{4}$ Departamento de Ciências Biológicas, Universidade Estadual de Feira de Santana - UEFS

Received February 12, 2010

Accepted May 6, 2010

\begin{abstract}
Toxoplasma gondii infection has been diagnosed in pigs all over the world. Economical losses are generally related to reproductive disorders. Toxoplasma infection is also a matter of public health because tissue cysts of the parasite may remain in pork and pork products, and become sources of human infection. The objective of this study was to evaluate the frequency and risk factors associated with Toxoplasma infection in certified and non-certified pig breeding farms in the Toledo microregion, in the State of Paraná, Brazil which includes the cities of Toledo, Nova Santa Rosa, Sao José das Palmeiras and Sao Pedro do Iguaçu. Relative frequency of infection was $13.4 \%$, independently of the type of farm. Logistic regression analysis showed that the following factors were associated with infection: absence of workers exclusive for each area of the farm, access of other animals to feeders and drinkers, lack of lids in drinkers, lack of rodent control measures, mean piglet number and weight at weaning per female.
\end{abstract}

Keywords: Toxoplasma gondii, prevalence, swine, risk factors, logistic regression analysis.

\section{Resumo}

A infecção pelo Toxoplasma gondii tem sido diagnosticada em suínos em todo o mundo. Perdas econômicas geralmente estão relacionadas a distúrbios reprodutivos. A infecção pelo Toxoplasma tem também importância em saúde pública, já que cistos teciduais do parasito podem persistir na carne e subprodutos oriundos de suínos, que servirão de fontes de infecção para o ser humano. O objetivo deste trabalho foi verificar a frequência e os fatores de risco associados à infecção pelo Toxoplasma em granjas de reprodutores suídeos certificados ou não da microrregião de Toledo, no Paraná, que inclui os municípios de Toledo, Nova Santa Rosa, São José das Palmeiras e São Pedro do Iguaçú. A frequência relativa de infecção foi $13,4 \%$, sem diferença com o tipo de granja. A análise de regressão logística demonstrou os seguintes fatores associados à infecção: não utilização de funcionários separados por área da granja, o acesso de animais ao cocho de ração e ao reservatório de água, a não utilização de tampa neste reservatório, a não prevenção de roedores, o número e peso médio de leitôes ao desmame por porca.

Palavras-chave: Toxoplasma gondii, prevalência, suíno, fatores de risco, análise de regressão logística. 


\section{Introduction}

Toxoplasma gondii was diagnosed as a disease agent in pigs in the United States in 1952 (FARRELL et al., 1952) and it was first described in Brazil in 1959 (SILVA, 1959). Since then other illnesses such as pneumonia, encephalitis, and abortions were attributed to infection with this protozoan parasite (DUBEY, 2009).

Studies on the factors associated with Toxoplasma infection in pigs showed that the highest rate of seropositivity was found among females (BEZERRA et al., 2009; MOURA et al., 2007; BONNA et al., 2006; ARAÚJO; SOUZA, 1997) and aged animals (DA SILVA et al., 2008; GARCIA et al., 1999; ARAÚJO; SOUZA, 1997). The age factor has special relevance for public health, as processed food products are often prepared with meat obtained from discarded old animals, therefore raising the risk of human infection.

Indeed, studies reported that infection with $T$. gondii is most likely to be found among older female reproducers (CARLETTI et al., 2005), or among animals from illegal abattoirs (BEZERRA et al., 2009), from intensive farming (BEZERRA et al., 2009; TSUTSUI et al., 2003) and, from farms with low degree of mechanization (DA SILVA et al., 2008).

Other factors associated with an increased chance of infection are contact with cats and rodents (TSUTSUI et al., 2003; PEREIRA, 2005), and farm management such as conditions of drinking water and the presence of wetlands within the farm (TSUTSUI et al., 2003).

To improve sanitary health in farms the Brazilian Ministry of Agriculture has issued a Swine Breeding Farm Certificate (SBFC) to award farms in good conditions for producing breeders. However, toxoplasmosis was not included among the six diseases of which farms must have status of free or controlled to attain the certificate. In recent decades levels of antibodies found in pigs have decreased in Brazil as well as in other countries with pig farming tradition (DUBEY, 2009). Nevertheless, the impact of this disease in pig farming, and of this animal as a potential parasite disseminator to humans, justifies studies of this infection in the entire production chain.

We investigated the prevalence of antibodies to Toxoplasma gondii by modified agglutination test, in pigs originated or not from SBFC farms located in the region of Toledo, Paraná, Brazil. The factors associated with the infection prevalence were also evaluated.

\section{Material and Methods}

The microregion of Toledo, located in the west of Paraná, is the largest producer of pigs in the state, and the third in Brazil. The pig population in Toledo consists of 410, 943 animals (BRASIL, 2008). To calculate the ideal sample size, from this population we selected 11 SBFC farms which contained a total of 6147 female reproducers (PARANÁ, 2009). Considering a prevalence of $23.5 \%$ as reported previously (VIDOTTO et al., 1990; TSUTSUI et al., 2003; CARLETTI et al., 2005; DA SILVA et al., 2008; MILLAR et al., 2008), 5\% error and confidence level of $10 \%$, we calculated that a minimum of 189 animals had to be sampled from SBFC farms for this study (KISH, 1995). Of the 678 farms which did not hold a SBFC and housed 21,794 female reproducers, we calculated a minimum sample size of 193 animals.

Farms were selected using a convenience sampling plan, taking into account previously established contacts with farmers willing to participate in the study. At least $10 \%$ of female reproducers were selected at random from each farm. Blood was collected by puncturing the jugular vein into test tubes, then centrifuged and the serum stored at $-20{ }^{\circ} \mathrm{C}$. Samples were collected from July 2008 to December 2009.

To detect antibodies to Toxoplasma gondii, serum samples were evaluated by the modified agglutination test - MAT (DESMONTS; REMINGTON, 1980). The serum was examined in the initial dilution of $1: 25$, and positive samples were titrated in dilutions folded from 1:25 to 1:3200. All samples with titers equal to or greater than 25 were considered positive. Known positive and negative controls derived from animals experimentally infected or not with $T$ gondii were used in each plate (ODORIZZI et al., 2010).

Each farmer answered a questionnaire containing queries regarding livestock management and animal health. This questionnaire was based on others published elsewhere (TSUTSUI et al., 2003; CAPORALI et al., 2005; PEREIRA, 2005). Seropositive frequencies and the responses to the questionnaires were analyzed to verify association of these results by Chi-square, Exact Fisher or $\mathrm{G}$ tests. Variables with $P$ values below 0.25 were used for further evaluation in multivariate models, applied according to the nature of the variables whether they were related to livestock management, to exposure to infection or animal production. Variables for logistic regression models were selected by backward stepwise method, computing the statistical significance of the exclusion of each variable regarding a $\mathrm{P}$ value $<0.05$. Each model had its fit verified using the test Hosmer-Lemeshow (BINGHAM et al., 2010).

This research was approved by the Ethics in Research Involving Animal Experimentation, Universidade Paranaense, protocol number $14843 / 2009$.

\section{Results and Discussion}

The final sample consisted of 606 animal samples, 334 (55.1\%) from eight SBFC farms, and 272 (44.9\%) from 15 non-SBFC farms. Figure 1 shows the location of the region examined, as well as the counties that originated the samples.

The absolute frequency of seropositive for the presence of anti-T. gondii antibodies was 81 (13.4, 95\% CI: 10.8 to 16.4$)$, with titers of 25 in 18 (22.2\%), 50 in 24 (29.6\%), 100 in 22 (27.2\%), 200 in $6(7.4 \%), 400$ in $3(3.7 \%), 800$ in $4(4.9 \%)$, 1600 in $2(2.5 \%)$ and 3200 in $2(2.5 \%)$. The majority of titers were on relatively low values, with $79 \%$ of samples with titers $\leq 100$. Titers below in MAT $(\leq 160)$ have been associated with chronic infection in pigs (DUBEY et al., 1997.) When considering the sample composition, frequency of seropositives did not vary between SBFC and non-SBFC farms (Table 1).

Several detection methods for serum antibodies to $T$. gondii have been used to evaluate infection in pigs producing slightly different results (DUBEY, 2009). However, no significant differences in 
the detection of antibodies in experimentally infected pigs were found using indirect immunofluorescence, modified agglutination and enzyme immunoassay (GARCIA et al., 2008).

Comparing our results to those reported by other studies conducted in the State of Paraná, the prevalence found by us was similar to that described by Tsutsui et al. (2003). The study evaluated 324 female reproducers derived from 22 farms from Northern Paraná and found 54 (10.4\%, 95\% CI: 13.0 to 21.1$)$ seropositive animals by indirect immunofluorescence.

However, studying farms from Northern Paraná, Vidotto et al. (1990) found that 267 of a total of 578 of female reproducers were seropositive (46.2\%, 95\% CI: 42.2 to 50.3$)$. The conflicting results showing a drop in the prevalence of infection by the parasite, during the period studied, were probably due to a substantial increase in the use of technological approaches in pig breeding in the region.

Studies on northwestern farms of Paraná detected anti-T. gondii antibodies in 18 of 78 female reproducers $(23.1,95 \% \mathrm{CI}$ : 15.1-33.6) (DA SILVA et al., 2008). The differences between these results and the results presented here is a matter of sampling. The study by $\mathrm{Da}$ Silva sampled animals from rustic farms with no or low degree of mechanization and low standards of animal health.

Analysis of the questionnaires allowed us to separate the queries in groups, according to the nature of the variable. Univariate analysis determined that which queries would be evaluated in each model (Table 2) by multivariate analysis (Table 3 ).

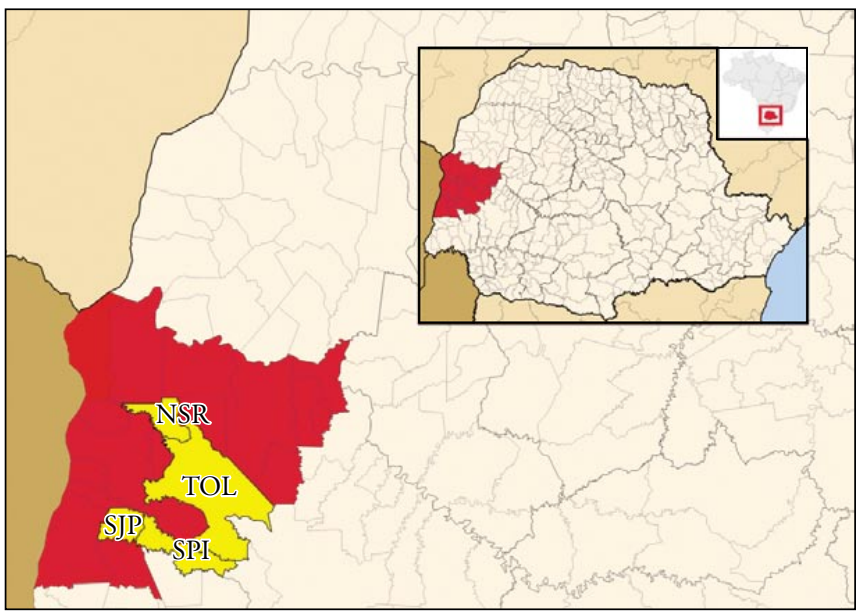

Figure 1. Microregion of Toledo, Paraná, depicting the Municipalities of Toledo (TOL), New Santa Rosa (NSR), São José das Palmeiras (SJP) and, São Pedro do Iguaçu (SPI). Adapted from Abreu (2006).
Analysis of variables related to livestock management showed that the "use of different employees according to the farm sector" was a protective factor, because the prevalence in the farms that adopted such practice was 6.4 versus $24.5 \%$ in those in which one employee had access to various sectors. This factor is directly related to the level of mechanization of the farm. Indeed, despite higher production costs, intensive breeding farms report earnings of US\$ 0.31 for every $100 \mathrm{~kg}$ of pig produced due to declining rates of infection by $T$. gondii (WANG et al., 2002).

Another significant variable for infection control was the covering of the water reservoir provided to the animals. Farms where this practice was adopted showed a rate of $7.7 \%$ infection compared to $29.0 \%$ prevalence in the farms where water reservoirs were left uncovered. Indeed, the chance to find seropositive pigs was 10.2 times higher on farms where the water reservoir was accessible to other animals such as dogs, chickens and rodents $(26.1 \%)$ than in those farms where such access was not reported (6.2\%). Furthermore, the access of animals such as rodents and chickens to the feed trough was significantly associated with infection with T. gondii, with 19.1 and $11.7 \%$ prevalence in herds with or without this report. Finally, absence of rodent control practices was associated with a higher frequency of infected animals.

Water and food contaminated with oocysts of T. gondii have been indicated as the main sources of infection for pigs (DUBEY, 2009), and several studies suggest that the presence of other animals is associated with an increased risk of infections (VIDOTTO et al., 1990; MATOS et al., 1999; TSUTSUI et al., 2003). This may be explained by the fact that animals can mechanically transport oocysts of the parasite, infecting the pig breeding area.

The role of rodents in the maintenance and transmission of toxoplasmosis in rural properties and especially in pig breeding has also been shown by several studies. Rodents drawn by corn or food prepared in the farm attract cats who pollute the environment with the parasite oocysts (VIDOTTO et al., 1990; GARCIA et al., 1999). The high seroprevalence in mice was associated with high rates of infection in pigs as well as the presence of young cats (WEIGEL et al., 1995). Studying farms under organic management, Kijlstra et al. (2008) showed a decrease in the prevalence of infection of $T$. gondii in pigs when measures of rodent control were used. The report also showed that the prevalence increased following withdrawal of rodent control measures in periods as short as three months of monitoring. The capture and ingestion of infected rodents by pigs could also be an alternative to animal infection (VIDOTTO et al., 1990).

Regarding the factors associated with animal production, for farms with fewer than 10 piglets/sow at weaning the prevalence of infection was 22.2 versus $8.2 \%$ when the number of piglets was

Table 1. Absolute frequency (N), relative (\%) and 95\% confidence interval (CI) of pigs reactive or not to the modified agglutination test employed to detect serum anti-Toxoplasma gondii, according to the type of farm. Toledo, Paraná, Brazil. 2008-2009.

\begin{tabular}{|c|c|c|c|c|c|c|c|c|}
\hline \multirow{2}{*}{$\begin{array}{l}\text { Farm } \\
\text { type }\end{array}$} & \multicolumn{3}{|c|}{ Non reactive } & \multicolumn{3}{|c|}{ Reactive } & \multicolumn{2}{|c|}{ Total } \\
\hline & $\mathbf{N}$ & $\%$ & CI & $\mathbf{N}$ & $\%$ & CI & $\mathbf{N}$ & $\%$ \\
\hline SBFC & 286 & 85.6 & $81.4-89.0$ & 48 & 14.4 & $11.0-18.5$ & 334 & 55.1 \\
\hline Non-SBFC & 239 & 87.9 & $83.4-91.2$ & 33 & 12.1 & $8.8-16.6$ & 272 & 44.9 \\
\hline Total & 525 & 86.6 & $83.7-89.1$ & 81 & 13.4 & $10.9-16.3$ & 606 & 100.0 \\
\hline
\end{tabular}

Statistics: $\chi^{2}=0.47$; P value $=0.493$. SBFC: Swine Breeding Farm Certificate. 
Table 2. Variables considered significant $(\mathrm{P}<0.25)$ in univariate analysis and then reviewed for inclusion in multivariate models to study the factors associated with infection by Toxoplasma gondii in pigs. Toledo, Paraná, Brazil. 2008-2009.

\begin{tabular}{|c|c|}
\hline Model & Variables \\
\hline $\begin{array}{l}\text { Livestock } \\
\text { management }\end{array}$ & $\begin{array}{l}\text { Uses different employees according to the farm } \\
\text { sector; } \\
\text { Animals separated according to categories; } \\
\text { Food storage time; } \\
\text { Water is treated before given to animals; } \\
\text { Water reservoir existent; } \\
\text { Cleans water reservoir; } \\
\text { Covers water reservoir; } \\
\text { Uses disinfectants; } \\
\text { Controls rodents; } \\
\text { Destination of the viscera from pigs slaughtered on } \\
\text { the farm; } \\
\text { Vaccinates animals; } \\
\text { Uses drugs in water or feed. }\end{array}$ \\
\hline Exposure & $\begin{array}{l}\text { Local of food storage; } \\
\text { Other animals have access to feed trough; } \\
\text { Water source; } \\
\text { Other animals have access to water reservoir; } \\
\text { Destination of pigs slaughtered in the property. }\end{array}$ \\
\hline Production & $\begin{array}{l}\text { Number of piglets per sow per birth; } \\
\text { Mean number of piglets weaned per sow; } \\
\text { Average weight of piglets at birth; } \\
\text { Average weight of piglets at weaning. }\end{array}$ \\
\hline
\end{tabular}

higher than $10 /$ sow. The average weight of piglets at weaning were lower $(<6 \mathrm{~kg})$ in those farms where the prevalence of infection was higher $(16.3 \%)$. In contrast farms where the prevalence of infection was lower $(7.3 \%)$ reported average weight larger than $6 \mathrm{~kg}$.

The impact of $T$. gondii on swine production have been shown mainly by losses due to reproductive problems (DUBEY, 2009), including abortions. Chronic infection effects on pig production were not investigated as reported in sheep (FREYRE et al., 1997). Despite the associations found in this work, other factors not necessarily infectious may affect production, and must be investigated in order to determine the real impact of Toxoplasma infection in swine productivity.

The present study demonstrates that pigs in the microregion of Toledo are subject to risk factors such as contact with other animal species, other animal access to water sources and feeding, and the presence of rodents. It is necessary to adopt biosafety measures aimed to interrupt the transmission cycle of the parasite. The study strengthens the thesis that yield losses in pig farming may be related to the presence of infection in animals. The mechanisms by which the parasite leads to these losses should be further investigated.

\section{Acknowledgments}

The authors would like to thank Monique Meiriele Piassa, Francisco de Oliveira and the Secretaria de Agricultura e Abastecimento - SEAB [Department of Agriculture and Supply]

Table 3. Final logistic regression models of factors associated with livestock management, exposure, production and reproduction used to study Toxoplasma gondii infection in pigs. Toledo, Paraná, Brazil. 2008-2009.

\begin{tabular}{|c|c|c|c|c|}
\hline Model & Variable & Odds ratio & CI 95\% & P value \\
\hline Livestock & Uses different employees according to the farm sector & 0.1 & $0.0-0.3$ & 0.0000 \\
\hline \multirow[t]{10}{*}{ Management } & Animals separated according to categories & $1.4 \times 10^{7}$ & $0.0-\mathrm{ND}$ & 0.9977 \\
\hline & Water reservoir existent & 0.2 & $0.0-2.4$ & 0.2176 \\
\hline & Cleans water reservoir & 0.0 & $0.0-\mathrm{ND}$ & 0.9987 \\
\hline & Covers water reservoir & 0.0 & $0.0-0.4$ & 0.0057 \\
\hline & Cleans the premises & $2.3 \times 10^{18}$ & $0.0-\mathrm{ND}$ & 0.9986 \\
\hline & Disinfects the premises & 0.0 & $0.0-\mathrm{ND}$ & 0.9977 \\
\hline & Control rodents & 0.1 & $0.0-0.4$ & 0.0019 \\
\hline & Destination of the viscera from slaughtered pigs & $4.1 \times 10^{8}$ & $0.0-\mathrm{ND}$ & 0.9976 \\
\hline & Vaccinates animals & 0.0 & $0.0-\mathrm{ND}$ & 0.9979 \\
\hline & Uses drugs in water or feed. & $8.4 \times 10^{7}$ & $0.0-\mathrm{ND}$ & 0.9978 \\
\hline \multirow[t]{4}{*}{ Exposure } & Local of food storage & 1.5 & $0.9-2.5$ & 0.1191 \\
\hline & Access of other animals to feed trough & 0.4 & $0.2-0.8$ & 0.0104 \\
\hline & Access of other animals to the water reservoir & 10.2 & $4.4-23.4$ & 0.0000 \\
\hline & Destination of the slaughtered pigs & 0.4 & $0.2-0.9$ & 0.0247 \\
\hline \multirow[t]{4}{*}{ Production } & Number of piglets per sow per birth & 0.6 & $0.3-1.1$ & 0.0860 \\
\hline & Mean number of piglets weaned per sow & 8.1 & $2.7-24.2$ & 0.0000 \\
\hline & Average weight of piglets at birth & 0.4 & $0.1-1.3$ & 0.1330 \\
\hline & Average weight of piglets at weaning & 0.1 & $0.1-0.3$ & 0.0000 \\
\hline
\end{tabular}

ND: not determined; CI 95\%: 95\% confidence interval. 
- Regional Toledo, for helping with data collection and initial processing of biological samples. The authors would also like to thank Fundação Araucária de Apoio ao Desenvolvimento Científico e Tecnológico do Paraná [The Araucaria Foundation for the Scientific and Technological Development of Paraná] (9365 Protocol) and the Universidade Paranaense - UNIPAR [Paranaense University] (Project in 1843), for the research grants and for the Scientific Initiation (PIBIC/UNIPAR) and Scientific Technical Training (PIT/UNIPAR) scholarships.

\section{References}

ABREU, L. R. Map locator of Paranás Toledo city. 2006. Disponível em: <http://pt.wikipedia.org/wiki/Ficheiro:Paraná_Municip_Toledo. svg>. Acesso em: 04 maio 2010.

ARAÚJO, F. A. P.; SOUZA, W. J. S. Antibody response against Toxoplasma gondii (Apicomplexa) measured by indirect fluorescent antibody technique in pigs naturally infected in the area of great Erechim, RS, Brazil. Arquivos da Faculdade de Veterinária da Universidade Federal do Rio Grande do Sul, v. 25, n. 2, p. 75-83, 1997.

BEZERRA, R. A. et al. Detecção de anticorpos anti-Toxoplasma gondii em suínos criados e abatidos no Estado da Bahia, Brasil. Revista Brasileira de Parasitologia Veterinária, v. 18, n. 3, p. 78-80, 2009.

BINGHAM, G. M.; BUDKE, C. M.; SLATER, M. R. Knowledge and perceptions of dog-associated zoonoses: Brazos County, Texas, USA. Preventive Veterinary Medicine, v. 93, n. 2-3, p. 211-221, 2010.

BONNA, I. C. F. et al. Estudo soroepidemiológico da infecção por Toxoplasma gondii em suínos e frangos, para abate, em região rural do Rio de Janeiro. Revista Brasileira de Ciência Veterinária, v. 13, n. 3, p. 186-189, 2006.

BRASIL. Instituto Brasileiro de Geografia e Estatística. Pecuária 2008. 2008. Disponível em: <http://www.ibge.gov.br/cidadesat>. Acesso em: 10 fev. 2010

CAPORALI, E. H. G. et al. Comparação de métodos para determinação da prevalência de anticorpos anti-Toxoplasma gondii em suínos dos Estados de São Paulo e Pernambuco, Brasil. Arquivos de Ciências Veterinárias e Zoologia da UNIPAR, v. 8, n. 1, p. 19-24, 2005.

CARLETTI, R. T. et al. Prevalência da infecção por Toxoplasma gondii em suínos abatidos no Estado do Paraná, Brasil. Semina: Ciências Agrárias, v. 26, n. 4 , p. 563-568, 2005.

DA SILVA, A. V. et al. Ocorrência de anticorpos anti-Toxoplasma gondii em suínos da região oeste do Paraná, Brasil. Veterinária e Zootecnia, v. 15 , n. 2, p. 263-266, 2008.

DESMONTS, G.; REMINGTON, J. S. Direct agglutination test for diagnosis of Toxoplasma infection: method for increasing sensitivity and specificity. Journal of Clinical Microbiology, v. 11, n. 6, p. 562-568, 1980.

DUBEY, J. P. et al. Long-term humoral antibody responses by various serologic tests in pigs orally inoculated with oocysts of four strains of Toxoplasma gondii. Veterinary Parasitology, v. 68, n. 1-2, p. 41-50, 1997.

DUBEY, J.P. Toxoplasmosis in pigs - The last 20 years. Veterinary Parasitology, v. 164, n. 2-4, p. 89-103, 2009.

FARREL, R. L. et al. Toxoplasmosis. 1. Toxoplasma isolated from swine. American Journal of Veterinary Research, v. 13, n. 47, p. 181-185, 1952.
FREYRE, A. et al. The incidence and economic significance of ovine toxoplasmosis in Uruguay. Veterinary Parasitology, v. 73, n. 1-2, p. 13-15, 1997.

GARCIA, J. L. et al. Evaluation of IFA, MAT, ELISAs and immunoblotting for the detection of anti-Toxoplasma gondii antibodies in paired serum and aqueous humour samples from experimentally infected pigs. Research in Veterinary Science, v. 84, n. 2., p. 237-242, 2008.

GARCIA, J. L. et al. Soroprevalência do Toxoplama gondii, em suínos, bovinos, ovinos e equinos e sua correlação com humanos, felinos e caninos, oriundos de propriedades rurais do norte do Paraná-Brasil. Ciência Rural, v. 29, n. 1, p. 91-97, 1999.

KIJLSTRA, A. et al. The role of rodents and shrews in the transmission of Toxoplasma gondii to pigs. Veterinary Parasitology, v. 156, n. 3-4, p. 183-190, 2008.

KISH, L. Survey Sampling. Indianapolis: Wiley-Interscience, 1995. $664 \mathrm{p}$.

MATOS, M. P. C. et al. Anticorpos para Toxoplasma gondii em soros de matrizes suínas de granjas que abastecem o mercado consumidor de Goiânia. A Hora Veterinária, v. 19, n. 109, p. 9-11, 1999.

MILLAR, P. R. et al. Toxoplasma gondii: estudo soro-epidemiológico de suínos da região sudoeste do estado do Paraná. Pesquisa Veterinária Brasileira, v. 28, n. 1, p. 15-18, 2008.

MOURA, A. B. et al. Ocorrência de anticorpos contra Toxoplasma gondii em suínos e ovinos abatidos no município de Guarapuava, PR, Brasil. Revista Brasileira de Parasitologia Veterinária, v. 16, n. 1, p. 54-56, 2007.

ODORIZZI, L. et al. Quantitative and morphometric changes of subpopulations of myenteric neurons in swines with toxoplasmosis. Autonomic Neuroscience: Basic \& Clinical, v. 155, n. 1, p. 68-72, 2010.

PARANÁ. Secretaria da Agricultura e do Abastecimento. Granjas GRSC no Paraná. 2009. Disponível em: <http://www.seab.pr.gov.br/arquivos/ File/defis/educacao/grsc_13out.pdf>. Acesso em: 10 out. 2009.

PEREIRA, I. C. Soroprevalência de anticorpos para Toxoplasma gondii em suínos e características epidemiológicas de estabelecimentos de criaçáo industrial e artesanal da regiáo de Pelotas, RS. 2005. 99 f. Dissertação (Mestrado)-Universidade Federal de Pelotas, Rio Grande do Sul.

SILVA, J. M. L. Sobre um caso de toxoplasmose espontânea em suínos. Arquivos da Escola Superior de Veterinária da Universidade Federal de Minas Gerais, v. 12, n. 1, p. 425-428, 1959.

TSUTSUI, V. S. et al. Soroepidemiologia e fatores associados a transmissão do Toxoplasma gondii em suínos do norte do Paraná. Archives of Veterinary Science, v. 8, n. 2, p. 27-34, 2003.

VIDOTTO, O. et al. Estudos epidemiológicos da toxoplasmose em suínos da região de Londrina - PR. Semina: Ciências Agrárias, v. 11, n. 1, p. 53-59, 1990.

WANG, C. H. et al. Toxoplasma gondii levels in swine operations: differences due to technology choice and impact on costs of production. Food Control, v. 13, n. 2, p. 103-106, 2002.

WEIGEL, R. M. et al. Rick factors for transmission of Toxoplasma gondii on swine farms in Illinois. Journal of Parasitology, v. 81, n. 5 , p. 736-741, 1995. 